\title{
Immunohistochemical analysis of gastrin-releasing peptide receptor (GRPR) and possible regulation by estrogen receptor $\beta c x$ in human prostate carcinoma
}

\author{
S. NAGASAKI ${ }^{1}$, Y. NAKAMURA ${ }^{1}$, T. MAEKAWA ${ }^{1}$, J. AKAHIRA ${ }^{1}$, Y. MIKI ${ }^{1}$, T. SUZUKI ${ }^{1,2}$, S. ISHIDOYA ${ }^{3}$, Y. ARAI ${ }^{3}$, H. SASANO \\ ${ }^{1}$ Department of Pathology, Tohoku University Graduate School of Medicine, Sendai, Japan; ${ }^{2}$ Department of Pathology and Histotechnology, \\ Tohoku University Graduate School of Medicine, Sendai, Japan; ${ }^{3}$ Department of Urology, Tohoku University Graduate School of Medicine, \\ Sendai, Japan \\ *Correspondence: yasu-naka@patholo2.med.tohoku.ac.jp
}

Received July 29, 2011 / Accepted October 26, 2011

\begin{abstract}
Gastrin-releasing peptide (GRP) belongs to the family of bombesin-like peptides. GRP was demonstrated to stimulate the proliferation and invasiveness of androgen-independent prostate carcinoma. GRP mediates its action through the membrane-bound receptor, GRP receptor (GRPR), which is characterized by a high-affinity binding for both GRP and bombesin. In human prostate cancer tissue, GRPR mRNA was reported to be detectable in more than $90 \%$ but its immunolocalizaition has not been reported. Therefore, in this study we immunolocalized GRPR in 51 human prostate cancer cases and correlated the findings with several clinicopathological parameters in order to beter understand the function and regulation of GRPR in human prostate cancer. GRPR was immnolocalized in carcinoma cells and their values were significantly associated with Gleason score and immunoreactivity of estrogen receptor $\beta c x(E R \beta c x)$ that is one of splicing variants of ligand dependent transcription factor, ER $\beta$, and considered to be prognostic factor of prostate cancer patients. The amounts of GRPR and ER $\beta c x$ mRNA in three prostate cancer cell lines PC-3, DU-145 and LNCaP evaluated by quantitative RT-PCR (qPCR) analysis were also significantly correlated. In addition, we established stable transformants of prostate carcinoma cell line PC-3 introduced with ER $\beta c x$, and confirmed that GRPR mRNA was induced in ER $\beta c x$ over-expressing PC-3 cells by qPCR analysis. These results also suggest that $\mathrm{ER} \beta \mathrm{cx}$ contributes to prostate cancer development possibly through mediating GRPR expression in carcinoma cells.
\end{abstract}

Key words: ERßcx, GRPR, prostate cancer

Gastrin-releasing peptide (GRP) belongs to the family of bombesin-like peptides that includes the amphibian peptide bombesin as well as the mammalian counter-parts GRP and neuromedin B [1]. Several previous studies demonstrated that growth stimulation of bombesin-like peptides played some roles in the process of human carcinogenesis [2-7]. In human prostate cancer, GRP was also reported to increase the proliferation and invasiveness of androgen-independent prostate cancer [8-11]. In addition, the secretion of GRP by neuroendocrine cells has been also proposed to cause prostate cancer progression, development of androgen independence, and poor prognosis [12]. GRP mediates its action through membrane-bound receptors. These receptors correspond to one of the subtypes of the bombesin-like peptide receptors, namely the GRP receptor (GRPR), which is characterized by a high-affinity binding for GRP and bombesin. GRPR also belongs to the members of the large superfamily of G-protein-coupled receptors with seven transmembrane domains. GRPR have been also detected in various types of tumor cell lines including prostate cancer cells [13-16]. In human prostate cancer tissue, GRPR mRNA was also reported to be detected in more than $90 \%$ of the cases examined, and to be involved in prostate cancer development by two different investigators $[17,18]$. However, GRPR immunolocalizatoin has not been studied in normal human prostate.

In order to further understand the mechanism of functions and regulation of GRPR in human prostate cancer, we immunolocalized GRPR and correlated the findings with clinicopathological parameters including ages, proste specific antigen (PSA) level, Gleason score, stage, lymph node status, 
neuroendocrine differentiation (NED) status, Ki67 labeling index (LI), androgen receptor (AR) LI, estrogen receptor $\beta$ $(E R \beta) L I$, and ER $\beta c x$ LI. ER $\beta c x$ is the one of well-studied isoform of $\mathrm{ER} \beta$ which is estrogen dependent transcription factor, and reported to be expressed abundantly in high-grade prostate carcinoma than low grade one $[19,20]$. In addition, clinical outcome of patients with high ER $\beta c x$ was worse than those with lower ER $\beta c x$ in human prostate carcinoma [20]. Therefore, ER $\beta c x$ is currently considered as one of the important prognostic factor in the patients with prostate carcinoma. In this study, we compared the status of GRPR with several clinicopathological parameters and demonstrate statistically significant correlation of GRPR status with ER $\beta \mathrm{cx}$ immunoreactivity. Moreover, we established stable transformants of well-documented prostate cancer cell line PC-3 cells with introducing $E R \beta c x$ vectors to analyze the biological functions of ER $\beta c x$. We then performed quantitative RT-PCR (qPCR) analysis in order to confirm whether GRPR was induced in ER $\beta c x$ over-expressing PC-3 cells.

\section{Materials and Methods}

Prostate Carcinoma Cases. 51 archival specimens of prostate carcinoma retrieved from patients who had under-went prostatectomy at Department of Urology, Tohoku University Hospital (Sendai, Japan). The mean age of the patients was 65.2 years (range: 47-77). All patients examined in this study did not receive radiation, chemotherapy, or hormone therapy prior to surgery. Clinical data, including patients' age, serum prostate specific antigen (PSA) concentration, clinical stages according to the International Union Against Cancer TMN classification (1987), lymph node status, and Gleason score were all retrieved from reviewing the charts of the patients. The histlogical grade of each tumor was evaluated by two of the authors (Y.N. and T.S.). All the specimens had been fixed with $10 \%$ formalin and embedded in paraffin wax at the Department of Pathology, Tohoku University Hospital. The Ethic's Committee at Tohoku University School of Medicine approved the research protocol for this study (2003-146).

Immunohistochemistry. A Histofine Kit (Nichirei, Tokyo, Japan) that employs the streptavidine-biotin amplification method was used in this study for immunostaining. Antigen retrieval was performed by heating the slides in an autoclave at $120^{\circ} \mathrm{C}$ for $5 \mathrm{~min}$ in citric acid buffer $(2 \mathrm{mM}$ citric acid and $9 \mathrm{mM}$ trisodium citrate dehydrate, $\mathrm{pH}$ 6.0). Mouse monoclonal antibodies against Ki-67, AR, ER $\beta$ and ER $\beta c x$ were purchased from DAKO Corporation (Glostrup, Denmark), GeneTex(SanAntonio, TX) and Acris Antibodies GmbH (Hiddenhausen, Germany) respectively. Rabbit polyclonal antibody against GRPR and chromogranin A ( $\mathrm{CgA}$ ) was purchased from GeneTex and DAKO Corporation respectively. The dilutions of primary antibodies were as follows: Ki-67, 1/50; AR, 1/100; ER $\beta, 1 / 1500$; ER $\beta c x, 1 / 500$; GRPR, $1 / 250$ and CgA, $1 / 2000$. The antigen-antibody complex was visualized with 3,3'-diaminobenzidine solution ( $1 \mathrm{mM}$, in $50 \mathrm{mM}$ Tris- $\mathrm{HCl}$ buffer $(\mathrm{pH} 7.6)$ and $0.006 \% \mathrm{H}_{2} \mathrm{O}_{2}$ ), and counterstained with hematoxylin. As a negative control, normal rabbit or mouse IgG was used instead of the primary antibodies, and no specific immunoreactivity was detected in these tissue sections.

Scoring of immunoreactivity. Ki-67, AR, ER $\beta$ and ER $\beta c x$ immnoreactivity was detected in the nucleus, and the immunoreactivity was evaluated in more than 1000 carcinoma cells for each case, and subsequently the percentage of immunoreactivity, i.e. labeling index (LI), was determined. GRPR immunoreactivity was tentatively classified into the following three groups:,$++>=50 \%$ positive carcinoma cells; +, $10 \%$ to $49 \%$ positive cells; and -, $0 \%$ to $9 \%$ negative cells. Neuroendocrine differentiation of prostate carcinoma cases was evaluated with immunohistochemistry of $\mathrm{CgA}$. CgA immunoreactivity detected in the cytoplasm, and evaluated using a semi-quantitative approach according to the results of previous report [21]. Briefly, carcinoma cases were classified as NED-negative when no CgA-positive cells were detected (scored 0 ), or when positively stained cells were found to be scattered throughout the tumor without any cluster formation (scored $1+$ ) with cluster being defined as the at least three stained cells situated so closely as to touch cell surface of each other. We defined NED-positive when at least one CgA-positive cluster (scored $2+$ ) or when a few to many clusters (scored $3+$ ) could be identified.

Cell lines and plasmids. Human prostate cancer cell line PC-3, DU-145 and LNCaP were provided from the Cell Resource Center for Biomedical Research, Institute of Development, Aging and Cancer, Tohoku University(Sendai, Japan). The cell lines were maintained in RPMI-1640 (Sigma-Aldrich, St.Louis, MO) supplemented with $10 \%$ fetal bovine serum (FBS; JRH Bioscience, Lenexa, KS). In this study, we used estrogen-responsive reporter plasmids pERE-Luc, containing Xenopus vitellogenin A2 estrogen-responsive element (ERE) [22]. The pRL-TK vectors were purchased from Promega (Madison, WI). Full length of cDNA for ER $\beta$ and $E R \beta c x$ were constructed in $\mathrm{pRc} / \mathrm{CMV}$ expression plasmid (Invitrogen Corporation, Carlsbad, CA) [23].

Establishment of PC-3 cells associated with ER $\beta c x-$ overexpression. In order to establish stable transformant expressing high levels of ER $\beta \mathrm{cx}$ protein in PC-3, ER $\beta \mathrm{cx}$ cDNA cloned into $\mathrm{pRc} / \mathrm{CMV}$ was transfected using TransIT-LT1 Transfection Reagent (Mirus Bio Corporation, Madison, WI) was used following the supplier's instruction. A control cell line was established by transfecting an empty expression plasmid. The clones expressing high levels of ER $\beta \mathrm{cx}$ mRNA was selected by G-418 (Sigma-Aldrich) treatment. Transfected PC-3 was cultured for 2 weeks with G-418, and clones acquired resistance against G-418 was subsequently isolated. More than 10 stable transformant clones were isolated and the levels of mRNA and protein expression of ER $\beta c x$ were subsequently confirmed by both qPCR and western blot analysis. Two of the clones, tentatively termed Mock-\#1 and Mock-\#2, ER $\beta c x-\# 7$ and ER $\beta c x-\# 8$ were used for further analysis, in this study. 
Luciferase assay. The luciferase assay was performed according to a previous report with some modification [24]. Briefly, pERE-Luc, pRL-TK and pRc/CMV-ER $\beta$ plasmids were used to analyze dominant negative effects of $E R \beta c x$ expressed in stable transformant. Cells were seeded at $1 \times 10^{5}$ cells/well in 24-well culture plates in RPMI 1640 supplemented with $10 \%$ FBS and allowed to adhere for $24 \mathrm{hr}$. Cultures were subsequentry washed twice with PBS. Cells were then cultured for $24 \mathrm{hr}$ in phenol-red-free RPMI1640 without FBS for serum deprivation. Transient transfection was carried out using TransIT-LT1 Transfection Reagents (Mirus Bio Corporation), and the luciferase activity of lysates were measured using a Dual-Luciferase Reporter Assay system (Promega) and Luminescencer-PSN(AB-2200) (Atto Co., Tokyo, Japan) after incubation with $100 \mathrm{nM} 17 \beta$-estradiol(Sigma-Aldrich) for $24 \mathrm{hr}$. The cells were also treated with the same volume of ethanol (final dilution- $0.05 \%$ ) for $24 \mathrm{hr}$ as controls. The transfection efficiency was normalized against Renilla luciferase activity using pRL-TK control plasmids, and the luciferase activity for each sample was evaluated as a ratio (\%) compared with that of controls.

qPCR analysis. Total RNA was extracted from the cells using TRIzol regents(Invitrogen Corporation), and cDNA was synthesized using QuantiTect reverse transcription kit (QIAGEN GmbH, Hilden, Germany). Real-time PCR was carried out using the LightCycler System and FastStart DNA Master SYBR Green I (Roche Diagnostics GmbH, Mannheim, Germany). The PCR primer sequences of ER $\beta c x$, GRPR, and ribosomal protein L13A ( RPL13A ) used in this study are as follows: $\mathrm{ER} \beta \mathrm{Cx}$ [ AB006589; forward 5'-GATCTTGTTCTGGACAGGGAT-3' and reverse 5'-AGGCCTTTTCTGCCCTC-3'], GRPR [ NM_005314; forward 5'-CTGATCCAGAGTGCTTACAA-3' and reverse 5'-CGGTACAGGTAGATGACATGA-3'], RLP13A [NM_012423; forward 5'-CCTGGAGGAGAAGAGGAAAGAGA-3' and reverse 5'-TTGAGGACCTCTGTGTATTTGTCAA-3']. An initial denaturing step of $95^{\circ} \mathrm{C}$ for 10 minutes was followed by 40 cycles of $95^{\circ} \mathrm{C}$ for 10 seconds; 10 seconds annealing at $68^{\circ} \mathrm{C}$; and elongation at $72^{\circ} \mathrm{C}$ for 10 seconds (GRPR and $\mathrm{RPL} 13 \mathrm{~A})$ and 15 seconds $(\mathrm{ER} \beta \mathrm{cx})$. The fluorescence intensity of the double-strand specific SYBR GreenI was read at $72^{\circ} \mathrm{C}$ (GRPR and RLP13A) and $83^{\circ} \mathrm{C}(\mathrm{ER} \beta \mathrm{cx}$ ) after the end of each extension step. In initial experiments, PCR products were purified and subjected to direct sequencing to verify amplification of the corresponding sequence. To determine the quantity of target cDNA transcript, cDNAs of known concentrations for target genes, and the housekeeping gene, RPL13A, were used to generate standard curves for qPCR [2527]. The mRNA level in each case was represented as a ratio of RLP13A and was evaluated as a ratio (\%) compared with that of each control [25-27]. Negative control experiments were done without cDNA substrate to examine the presence of exogenous contaminant DNA.

Immunoblotting. The cell protein was extracted using M-PER Mammalian Protein Extraction Reagent (Pierce
Biotechnology, Rockford, IL) with Halt Protease Inhibitor Cocktail(Pierce Biotechnology), according to instruction manual. The concentration of the protein included in cell lysate was measured using Protein Assay Kit Wako (Wako Pure Chemical Industries, Osaka, Japan)). $20 \mu \mathrm{g}$ of the protein (whole cell extracts) were subjected to SDSPAGE( $10 \%$ acrylamide gel). Following SDS-PAGE, proteins were transferred onto Hybond P polyvinylidene difluoride membrane (GE Healthcare, Buckinghamshire, England) using Mini Trans-Blot Cell and Power/Pac200 (Bio-Rad Laboratories, Hercules, CA). The blots were blocked in $5 \%$ non-fat dry skim milk for $1 \mathrm{hr}$ at room temperature, and were then incubated with a 1/1000 dilution of human ER $\beta$ antibody (GeneTex Inc., TX, USA), which detects both wtER $\beta$ and ER $\beta c x$, for overnight at $4{ }^{\circ} \mathrm{C}$. After incubation with anti-mouse IgG horseradish peroxidase (GE Healthcare) for $1 \mathrm{hr}$ at room temperature, antibody-protein complexes on the blots were detected using ECL-plus western blotting detection reagents (GE Healthcare). The protein bands were visualized with LAS- 1000 cooled CCDcamera chemiluminescent image analyzer (Fuji Photo Film Co, Tokyo, Japan).

Statistical Analysis. Statistical analysis was done using the StatView 5.0J software (SAS Institute, Cary, NC). In an analysis of the possible correlation between immunoreactivity and clinicopathologic variables, values for the patient age, serum PSA level, and LI for Ki-67, AR, ER $\beta$ and ER $\beta \mathrm{cx}$ were presented as the mean $\pm 95 \%$ confidence interval (95\% CI). An association between GRPR immunoreactivity and each clinicopathological parameters were evaluated in a Spearman's rank correlation test. In the other studies, results were expressed as mean $\pm S D$, and analyzed by a Bonferroni test. In all statistical analysis, a $p$-value $<0.05$ was considered to indicate statistical significance.

\section{Results}

Immunnohistochemistry and correlation between GRPR immunoreactivity and clinicopathologic variables in 51 prostate carcinoma patients. GRPR immunoreactivity was detected in the cytoplasm of prostate carcinoma cells, while immunoreactivity of $E R \beta c x$ was detectable in the nuclei of prostate carcinoma cells (Fig.1). Results of associations between GRPR immunoreactivity and clinicopathologic variables in 51 prostate carcinoma patients were summarized in Table1. The number of cases with immunoreactive GRPR in each group was summarized as follows: -, 28 cases $(54.9 \%) ;+, 18$ cases $(35.3 \%)$; and ,++ 5 cases $(9.8 \%)$. The status of GRPR immunoreactivity was also significantly associated with Gleason score and $\mathrm{ER} \beta \mathrm{cx}$ immunoreactivity of the cases, whereas there were no significant associations between GRPR and other clinicopathologic variables, including patients' age, serum PSA level, pathological stage, lymph node status, Ki-67 LI, AR LI, ER $\beta$ LI and NED status. 

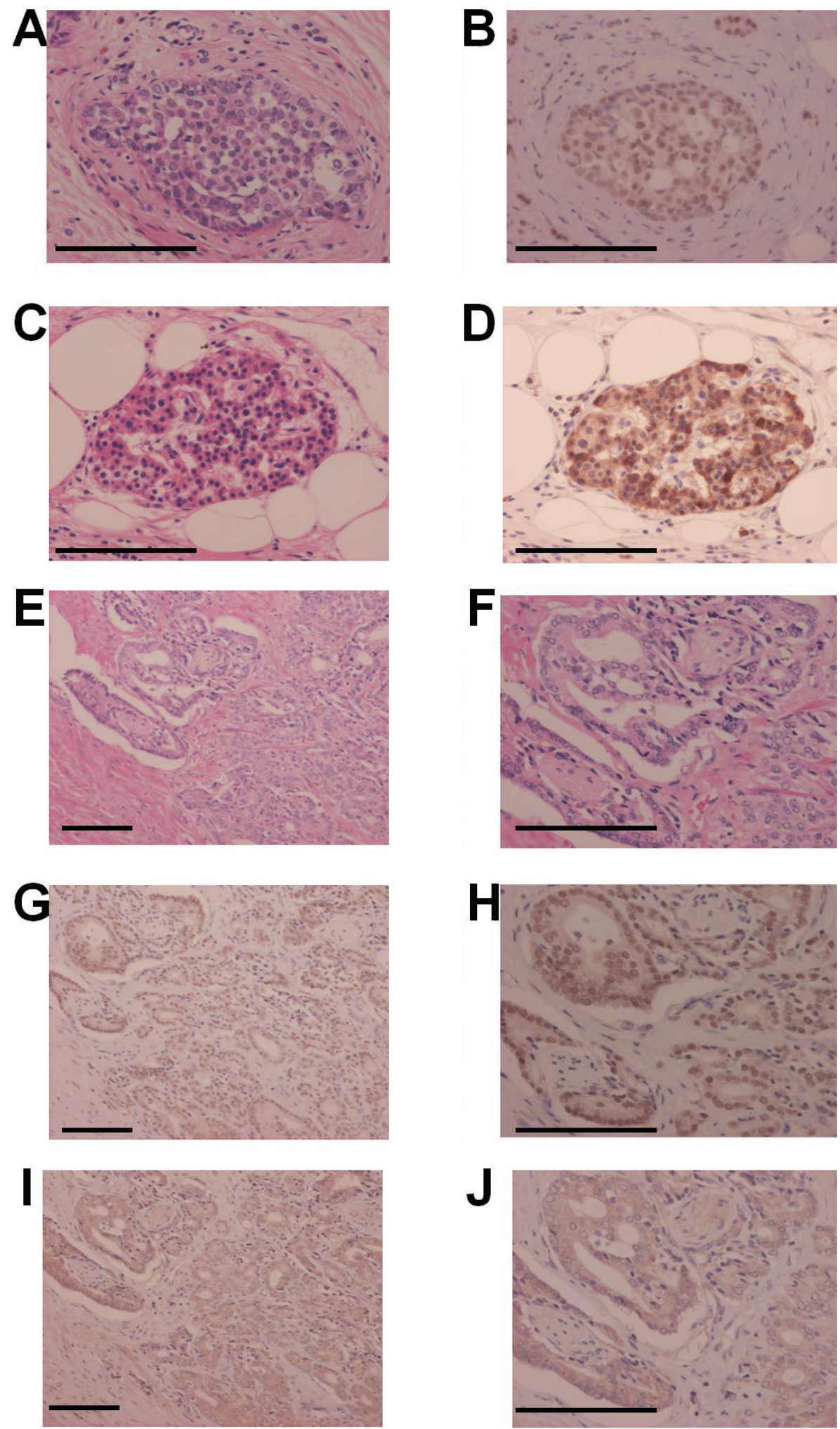

Figure 1. H\&E staining (A) and immunohistochemistry of $\operatorname{ER} \beta c x(B)$ in human breast carcinoma (positive control). H\&E staining (C) and immunohistochemistry of GRPR (D) in the islet of human pancreas (positive control). H\&E staining (E, F), immunohistochemistry of ER $\beta$ cx (G, H) and GRPR $(I, J)$ in human prostate carcinoma. Immunoreactivity of ER $\beta c x$ and GRPR were detected in the nuclei and cytoplasm of prostate carcinoma cells, respectively. Scale bar $=100 \mu \mathrm{m}$ 
Table1. Association between GRPR immunoreactivity and clinicopathological parameters in 51 Prostate Carcinoma

\begin{tabular}{|c|c|c|c|c|c|c|c|}
\hline & \multicolumn{6}{|c|}{ GRPR immunoreactivity } & \multirow[t]{2}{*}{$P$ value } \\
\hline & \multicolumn{2}{|c|}{$\begin{array}{c}- \\
(n=28)\end{array}$} & \multicolumn{2}{|c|}{$\begin{array}{c}+ \\
(n=18)\end{array}$} & \multicolumn{2}{|c|}{$\begin{array}{c}++ \\
(n=5)\end{array}$} & \\
\hline Ages(years) & \multicolumn{2}{|c|}{$66.3 \pm 2.2$} & \multicolumn{2}{|c|}{$64.1 \pm 2.8$} & \multicolumn{2}{|c|}{$64.0 \pm 8.3$} & 0.1843 \\
\hline PSA(ng/mL) & \multicolumn{2}{|c|}{$11.9 \pm 3.7$} & \multicolumn{2}{|c|}{$14.3 \pm 7.0$} & \multicolumn{2}{|c|}{$16.8 \pm 23.6$} & 0.4075 \\
\hline \multicolumn{8}{|l|}{ Gleason score } \\
\hline 6 & 14 & $(27.5 \%)$ & 0 & $(0.0 \%)$ & 0 & $(0.0 \%)$ & \\
\hline 7 & 8 & $(15.7 \%)$ & 11 & $(21.6 \%)$ & 0 & $(0.0 \%)$ & \\
\hline 8 & 4 & $(7.8 \%)$ & 4 & $(7.8 \%)$ & 5 & $(9.8 \%)$ & \\
\hline 9 & 2 & $(3.9 \%)$ & 3 & $(5.9 \%)$ & 0 & $(0.0 \%)$ & 0.0003 \\
\hline \multicolumn{8}{|l|}{ Stage } \\
\hline pT2 & 14 & $(27.5 \%)$ & 5 & $(9.8 \%)$ & 2 & $(3.9 \%)$ & \\
\hline pT3 & 14 & $(27.5 \%)$ & 13 & $(25.5 \%)$ & 3 & $(5.9 \%)$ & 0.2156 \\
\hline \multicolumn{8}{|l|}{ Lymph node status } \\
\hline Positive & 1 & $(2.0 \%)$ & 2 & $(3.9 \%)$ & 0 & $(0.0 \%)$ & \\
\hline Negative & 27 & $(52.9 \%)$ & 16 & $(31.4 \%)$ & 5 & $(9.8 \%)$ & 0.6045 \\
\hline Ki-67 LI (\%) & \multicolumn{2}{|c|}{$7.3 \pm 2.4$} & \multicolumn{2}{|c|}{$9.1 \pm 2.5$} & \multicolumn{2}{|c|}{$6.0 \pm 5.3$} & 0.3431 \\
\hline AR LI (\%) & \multicolumn{2}{|c|}{$71.6 \pm 8.2$} & \multicolumn{2}{|c|}{$73.7 \pm 13.1$} & \multicolumn{2}{|c|}{$81.2 \pm 9.6$} & 0.2946 \\
\hline ER $\beta$ LI (\%) & \multicolumn{2}{|c|}{$39.1 \pm 9.8$} & \multicolumn{2}{|c|}{$46.8 \pm 16.5$} & \multicolumn{2}{|c|}{$40.0 \pm 37.5$} & 0.7310 \\
\hline ER $\beta c x$ LI (\%) & \multicolumn{2}{|c|}{$3.7 \pm 2.2$} & \multicolumn{2}{|c|}{$11.9 \pm 5.0$} & \multicolumn{2}{|c|}{$19.2 \pm 16.9$} & $<0.0001$ \\
\hline \multicolumn{8}{|l|}{ NED status } \\
\hline Positive & 2 & $(3.9 \%)$ & 4 & $(7.8 \%)$ & 1 & $(2.0 \%)$ & \\
\hline Negative & 26 & $(51.0 \%)$ & 14 & $(27.5 \%)$ & 4 & $(7.8 \%)$ & 0.3185 \\
\hline
\end{tabular}

Data are presented as means $\pm 95 \%$ confidence interval. All other values represent the number of cases and percentage. Difference between each groups were determined by Spearman's rank correlation test. $P$ values less than 0.05 were considered significant, and were represented in boldface.

Stable over-expression of ER $\beta c x$ in PC-3 cells. ER $\beta c x$ is expressed in PC-3 cell line at the basal level but its level of corresponding mRNA and protein were near or below the detection limit. PC-3 cells were therefore stably transfected with human $E R \beta c x$ in order to clarify the function of $E R \beta c x$. Following the process of G-418 selection, the levels of ER $\beta \mathrm{cx}$ mRNA expression were evaluated using qPCR, and the clones that strongly expressed ER $\beta c x$ mRNA were selected as positive clones in this experiment (Fig.2A). Expression of ER $\beta c x$ protein was also evaluated using immunoblotting analysis (Fig.2B). We subsequently obtained two over expressing clones termed $E R \beta c x-\# 7$ and $E R \beta c x-\# 8$. Luciferase reporter gene assay was performed in order to further confirm the functionality of the ER $\beta c x$ that was reported to block binding of ERs to estrogen responsive element and to function as dominant negative factors against ERs. ER $\beta$ expression vector and EREreporter vector were transiently transfected to Mock-\#1 and ER $\beta c x-\# 7$ described above. ERE-dependent transactivation via $E R \beta$ by estradiol was significantly inhibited in ER $\beta c x-\# 7$ compared to Mock-\#1 (Fig.2C).

GRPR mRNA expression in ER $\beta c x$ over-expressing PC3 cells using qPCR. We performed qPCR analysis for GRPR mRNA in the control strains transfected with empty vector, Mock-\#1 and Mock-\#2, and test strains over-expressing ER $\beta c x$, $\mathrm{ER} \beta c \mathrm{cx}-\# 7$ and ER $\beta c \mathrm{cx}-\# 8$. Results of qPCR analysis were sum- marized in Fig.3A. The levels of GRPR mRNA expression in $E R \beta c x-\# 7$ and $E R \beta c x-\# 8$ were significantly higher ( 2 to 3 fold $)$ than that of Mock-\#1 and Mock-\#2.

ER $\beta c x$ and GRPR mRNA expression in PC-3, DU-145 and LNCaP using qPCR. Results of qPCR analysis were summarized in Fig.3B. The amounts of ER $\beta c x$ and GRPR mRNA expression were relatively higher in PC-3 than in DU-145 and LNCaP. The amounts of mRNA of these two genes were extremely low in androgen-dependent prostate cancer cell line LNCaP.

\section{Discussion}

GRPR expression was reported in human prostate cancer by $\mathrm{qPCR}$ analysis or receptor autoradiography using radiolabeled ligand for GRPR but GRPR immunolocalozation has not been reported in the literature to the best of our knowledge $[17,18]$. Therefore, this is the first immunohistochemical study of GRPR in human prostate carcinoma. Results of our study demonstrated that $45 \%(+; 35 \%,++; 10 \%)$ of the cases examined demonstrated positive immunoreactivity in the cytoplasm of the carcinoma cells. In addition, results of this our present study demonstrated statistically significant positive correlation between GRPR immunoreactivity and Gleason score, the most well-established prognostic factor 
A

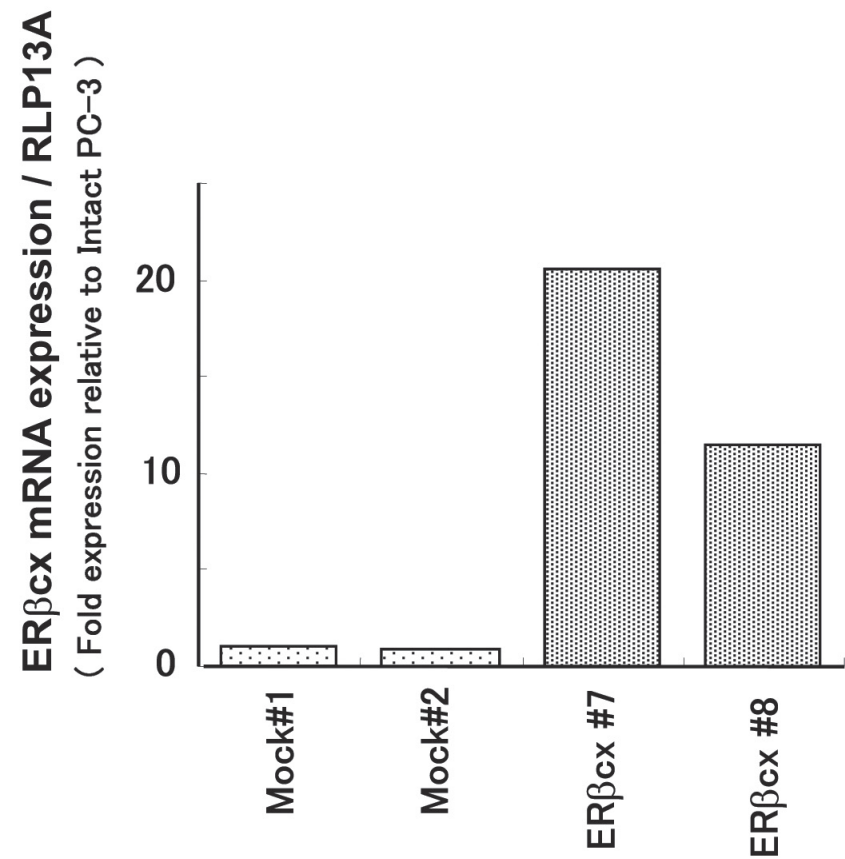

B
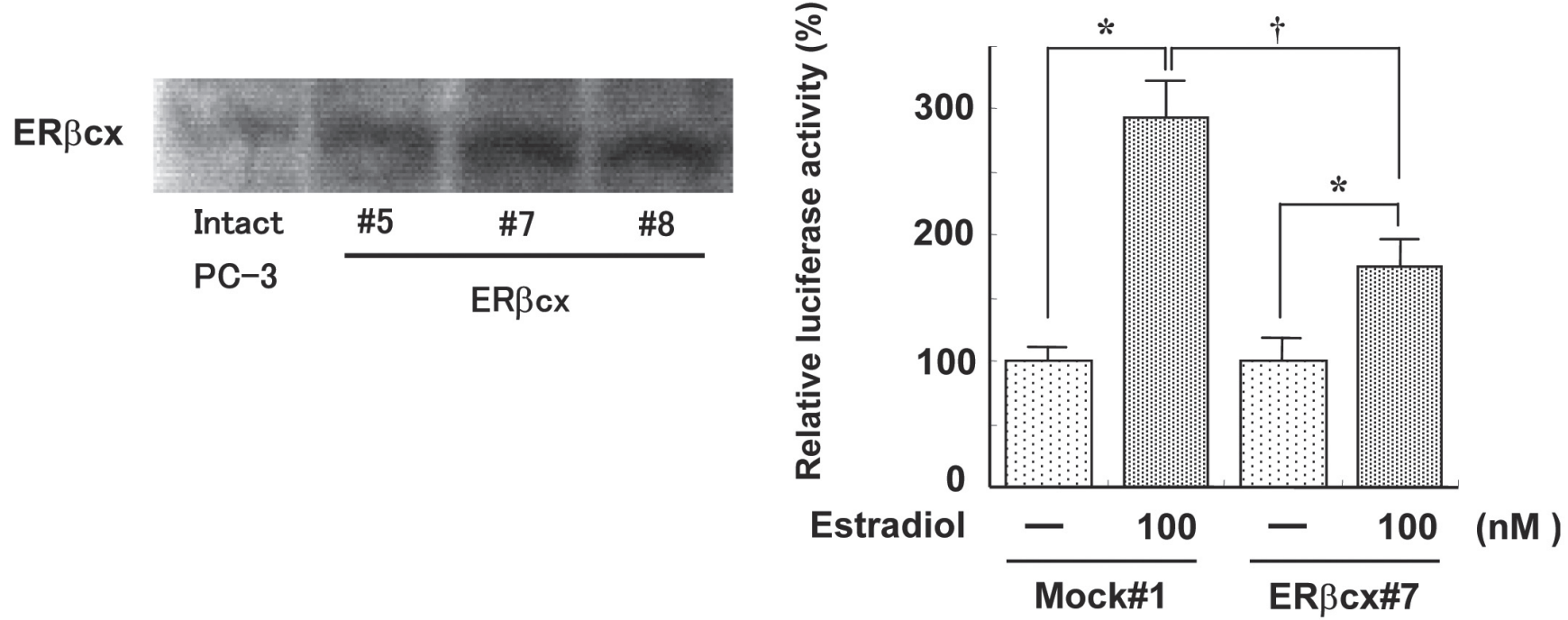

Figure 2. Isolation of transformants of PC-3 cells stably expressing ER $\beta \mathrm{cx}$.

A: Relative expression of ER $\beta c x$ in stably trasnfected with $\mathrm{pRc} / \mathrm{CMV}$ or $\mathrm{pRc} / \mathrm{CMV}$-ER $\beta \mathrm{cx}$ vector in prostate cancer cell lines PC-3 studied by qPCR. High levels of ER $\beta c x$ mRNA expression was detected ( 10 to $20 \mathrm{fold}$ ) in ER $\beta \mathrm{cx}-\# 7$ and ER $\beta \mathrm{cx}-\# 8$ compared to Mock-\#1 and Mock-\#2.

$B$ : Immunoblotting for ER $\beta c x$ in stably trasnfected with $p R c / C M V-E R \beta c x$ vector in prostate cancer cell lines PC-3

C: Results of dominant negative effect of ER $\beta \mathrm{cx}$ expressed in stably transfected PC-3. Mock-\#1 and ER $\beta \mathrm{cx}$-\#7 were transiently transfected with pERELuc and pRc/CMV-ER $\beta$ plasmid, and treated with estradiol(100nM) for $24 \mathrm{hr}$. The luciferase activity was evaluated as a ratio(\%) compared to that of controls. Data are presented as mean \pm S.D. $(n=3) . p<0.05$ vs each control $\left(^{*}\right)$ or induction ratio between each cell line $(\dagger)$.

in the patient with prostate carcinoma [28]. This correlation suggests also that the GRP secreted from neuroendocrne cells exert proliferation-stimulating effects via GRPR expressed in prostate cancer cells. Neuroendocrine differentiation is a common feature of adenocarcinoma of the prostate, and neuroendocrine differentiation is generally considered to be associated with aggressive biological behaviors in prostate carcinoma [29]. In addition, GRP/Bombesin antagonist was 

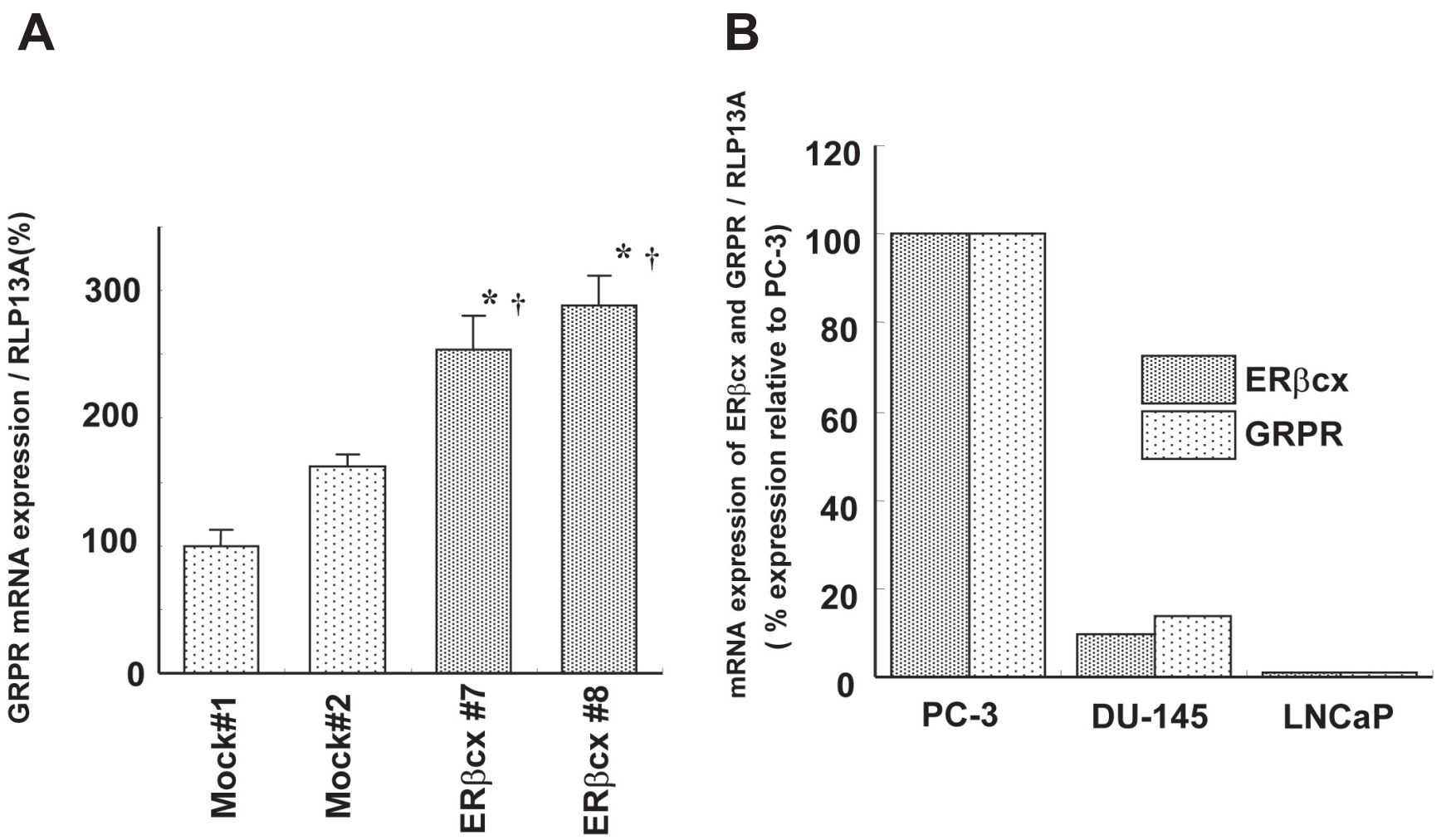

Figure 3. qPCR analysis of GRPR mRNA in ER $\beta$ cx stably expressing PC-3 cells and human prostate cancer cell lines.

A: Relative expression of GRPR mRNA in stably trasnfected with pRc/CMV or pRc/CMV-ER $\beta c x$ vector in prostate cancer cell lines PC-3 was analyzed by qPCR. 2 to 3 fold induction of GRPR mRNA was detected in ER $\beta$ cx-\#7 ER $\beta$ cx-\#8 compared to Mock-\#1 and Mock-\#2. The expression level of GRPR mRNA was evaluated as a ratio(\%) compared to that of Mock-\#1. Data are presented as mean \pm S.D. $(n=3)$. $p<0.05$ vs Mock-\#1( $\left.{ }^{*}\right)$ or Mock-\#2( $\left.\dagger\right)$.

B: Comparison of mRNA expression of ER $\beta c x$ and GRPR in three prostate cancer cell lines, PC-3, DU-145 and LNCaP. Relative expression of ER $\beta c x$ and GRPR mRNA in each cell lines were analyzed by qPCR. Expression pattern of ER $\beta c x$ and GRPR were extremely resembled between three cell lines.

reported to significantly suppress the growth or proliferation of PC-3 tumors implanted into the nude mice [30]. Therefore, all of these data above and our present results suggested that the up-regulation of GRPR in prostate carcinoma cells may partially explain these clinical behaviors of prostate adenocarcinomas with neuroendocrine differentiation. However, GRPR immunoreactivity was not correlated with NED status in our study evaluated by chromogranine A and it awaits further investigations for clarification.

The significant correlations were also detected between the status of GRPR and immunoreactivity of estrogen receptor $\beta$ $(\mathrm{ER} \beta)$ isoform 2, called $\mathrm{ER} \beta \mathrm{cx}$ in prostate carcinoma cases. $\mathrm{ER} \beta c \mathrm{cx}$ is the one of well-studied isoform of $\mathrm{ER} \beta$ and expressed in several types of human malignancies including human prostate carcinoma [31-37]. ER $\beta \mathrm{cx}$ was also more abundant in high-grade prostate carcinomas than low grade ones [20]. In addition, clinical outcome of patients with higher $\mathrm{ER} \beta \mathrm{cx}$ was worse than those with lower $\mathrm{ER} \beta \mathrm{cx}$ in human prostate cancer [20]. Therefore, ER $\beta c x$ is currently considered as one of the important prognostic factors in the patients with prostate carcinoma. These reports above and our finding suggest that the expression of GRPR could be, at least partially, mediated via $E R \beta c x$ in direct or indirect manner in human prostate carcinoma cells and sequentially promote the progression of prostate cancer. Results of qPCR analysis in this our present study in which the amounts of ER $\beta c x$ and GRPR mRNA were evaluated in three different prostate cancer cell lines also strongly supports the hypothesis discussed above. In addition, an induction of GRPR mRNA expression was confirmed in ER $\beta$ cx over-expressing PC-3 cells. However, it awaits further investigations including some in vitro investigations to demonstrate the regulation of GRPR gene expression through $\mathrm{ER} \beta \mathrm{cx}$ in detail.

In summary, we immunolocalized GRPR in 51 human prostate carcinomas and the status of GRPR was correlated with Gleson score and ER $\beta c x$ LI. These findings also indicates that $\mathrm{ER} \beta \mathrm{cx}$ contribute to prostate cancer development possibly through mediating GRPR expression in carcinoma cells.

Acknowledgments: We appreciate the skillful technical assistance of Mr. Katsuhiko Ono, Ms. Miki Mori and Ikumi Miura (Department of Pathology, Tohoku University School of Medicine). This work was supported by the grant from the Yamaguchi Endocrine Research Association. 


\section{References}

[1] ERSPAMER V. Discovery, isolation, and characterization of bombesin-like peptides. Ann N Y Acad Sci 1988; 547: 3-9 http://dx.doi.org/10.1111/j.1749-6632.1988.tb23870.x

[2] GIACCHETTI S, GAUVILLE C, DE CREMOUX P, BERTIN L, BERTHON P, et al. Characterization, in some human breast cancer cell lines, of gastrin-releasing peptide-like receptors which are absent in normal breast epithelial cells. Int J Cancer 1990; 46: 293-298 http://dx.doi.org/10.1002/ijc.2910460226

[3] YANO T, PINSKI J, GROOT K, SCHALLY AV. Stimulation by bombesin and inhibition by bombesin/gastrin-releasing peptide antagonist RC-3095 of growth of human breast cancer cell lines. Cancer Res 1992; 52: 4545-4547

[4] NELSON J, DONNELLY M, WALKER B, GRAY J, SHAW $\mathrm{C}$, et al. Bombesin stimulates proliferation of human breast cancer cells in culture. Br J Cancer 1991; 63: 933-936 http:// dx.doi.org/10.1038/bjc.1991.204

[5] LANGO MN, DYER KF, LUI VW, GOODING WE, GUBISH $\mathrm{C}$, et al. Gastrin-releasing peptide receptor-mediated autocrine growth in squamous cell carcinoma of the head and neck. J Natl Cancer Inst 2002; 94: 375-383 http://dx.doi.org/10.1093/ jnci/94.5.375

[6] MOODY TW, LEYTON J, GARCIA-MARIN L, JENSEN RT. Nonpeptide gastrin releasing peptide receptor antagonists inhibit the proliferation of lung cancer cells. Eur J Pharmacol 2003; 474: 21-29 http://dx.doi.org/10.1016/S00142999(03)01996-4

[7] THOMAS SM, GRANDIS JR, WENTZEL AL, GOODING WE, LUI VW, et al. Gastrin-releasing peptide receptor mediates activation of the epidermal growth factor receptor in lung cancer cells. Neoplasia 2005; 7: 426-431 http://dx.doi. org/10.1593/neo.04454

[8] BOLOGNA M, FESTUCCIA C, MUZI P, BIORDI L, CIOMEI M. Bombesin stimulates growth of human prostatic cancer cells in vitro. Cancer 1989; 63: 1714-1720 http://dx.doi.org/10.1002/1097-0142(19900501)63:9<1714:: AID-CNCR2820630912>3.0.CO;2-H

[9] MILOVANOVIC SR, RADULOVIC S, GROOT K, SCHALLY AV. Inhibition of growth of PC-82 human prostate cancer line xenografts in nude mice by bombesin antagonist RC-3095 or combination of agonist [D-Trp6]luteinizing hormone-releasing hormone and somatostatin analog RC-160. Prostate 1992; 20: 269-280 http://dx.doi. org/10.1002/pros.2990200403

[10] FESTUCCIA C, GUERRA F, D'ASCENZO S, GIUNCIUGLIO $\mathrm{D}, \mathrm{ALBINI} A$, et al. In vitro regulation of pericellular proteolysis in prostatic tumor cells treated with bombesin. Int J Cancer 1998; 75: 418-431 http://dx.doi.org/10.1002/(SICI)10970215(19980130)75:3<418::AID-IJC16>3.0.CO;2-4

[11] HOOSEIN NM, LOGOTHETIS CJ, CHUNG LW. Differential effects of peptide hormones bombesin, vasoactive intestinal polypeptide and somatostatin analog RC-160 on the invasive capacity of human prostatic carcinoma cells. J Urol 1993; 149: 1209-1213

[12] APRIKIAN AG, HAN K, GUY L, LANDRY F, BEGIN LR, et al. Neuroendocrine differentiation and the bombesin/gastrin- releasing peptide family of neuropeptides in the progression of human prostate cancer. Prostate Suppl 1998; 8: 52-61

[13] APRIKIAN AG, HAN K, CHEVALIER S, BAZINET M, VIALLET J. Bombesin specifically induces intracellular calcium mobilization via gastrin-releasing peptide receptors in human prostate cancer cells. J Mol Endocrinol 1996; 16: 297-306 http://dx.doi.org/10.1677/jme.0.0160297

[14] WU JM, HOANG DO, FELDMAN RI. Differential activation of human gastrin-releasing peptide receptor-mediated responses by bombesin analogs. Mol Pharmacol 1995; 47: 871-881

[15] REILE H, ARMATIS PE, SCHALLY AV. Characterization of high-affinity receptors for bombesin/gastrin releasing peptide on the human prostate cancer cell lines PC-3 and DU-145: internalization of receptor bound 125I-(Tyr4) bombesin by tumor cells. Prostate 1994; 25: 29-38 http://dx.doi.org/10.1002/ pros.2990250105

[16] FELDMAN RI, BARTHOLDI MF, WU JM. Bombesin-like peptide receptor subtypes promote mitogenesis, which requires persistent receptor signaling. Mol Pharmacol 1996; 50: 1346-1354

[17] MARKWALDER R, REUBI JC. Gastrin-releasing peptide receptors in the human prostate: relation to neoplastic transformation. Cancer Res 1999; 59: 1152-1159

[18] SUN B, HALMOS G, SCHALLY AV, WANG X, MARTINEZ $M$. Presence of receptors for bombesin/gastrin-releasing peptide and mRNA for three receptor subtypes in human prostate cancers. Prostate 2000; 42: 295-303 http://dx.doi. org/10.1002/(SICI) 1097-0045(20000301)42:4<295::AIDPROS7>3.0.CO;2-B

[19] MOORE JT, MCKEE DD, SLENTZ-KESLER K, MOORE LB, JONES SA, et al. Cloning and characterization of human estrogen receptor beta isoforms. Biochem Biophys Res Commun 1998; 247: 75-78 http://dx.doi.org/10.1006/bbrc.1998.8738

[20] FUJIMURA T, TAKAHASHI S, URANO T, OGAWA S, OUCHI Y, et al. Differential expression of estrogen receptor beta (ERbeta) and its C-terminal truncated splice variant ERbetacx as prognostic predictors in human prostatic cancer. Biochem Biophys Res Commun 2001; 289: 692-699 http:// dx.doi.org/10.1006/bbrc.2001.6038

[21] GUNIA S, ALBRECHT K, KOCH S, HERRMANN T, ECKE T, et al. Ki67 staining index and neuroendocrine differentiation aggravate adverse prognostic parameters in prostate cancer and are characterized by negligible inter-observer variability. World J Urol 2008; 26: 243-250 http://dx.doi.org/10.1007/ $\underline{\mathrm{s} 00345-008-0257-0}$

[22] SAJI S, OKUMURA N, EGUCHI H, NAKASHIMA S, SUZUKI A, et al. MDM2 enhances the function of estrogen receptor alpha in human breast cancer cells. Biochem Biophys Res Commun 2001; 281: 259-265 http://dx.doi.org/10.1006/ bbrc.2001.4339

[23] SAJI S, OMOTO Y, SHIMIZU C, WARNER M, HAYASHI Y, et al. Expression of estrogen receptor (ER) (beta)cx protein in ER(alpha)-positive breast cancer: specific correlation with progesterone receptor. Cancer Res 2002; 62: 4849-4853

[24] SAKAMOTO T, EGUCHI H, OMOTO Y, AYABE T, MORI H, et al. Estrogen receptor-mediated effects of tamoxifen on hu- 
man endometrial cancer cells. Mol Cell Endocrinol 2002; 192: 93-104 http://dx.doi.org/10.1016/S0303-7207(02)00086-2

[25] NAKAMURA Y, SUZUKI T, IGARASHI K, KANNO J, FURUKAWA T, et al. PTOV1: a novel testosterone-induced atherogenic gene in human aorta. J Pathol 2006; 209: 522531http://dx.doi.org/10.1002/path.1993

[26] NAKAMURA Y, SUZUKI S, SUZUKI T, ONO K, MIURA I, et al. MDM2: a novel mineralocorticoid-responsive gene involved in aldosterone-induced human vascular structural remodeling. Am J Pathol 2006;169:362-371 http://dx.doi. org/10.2353/ajpath.2006.051351

[27] SUZUKI T, HAYASHI S, MIKI Y, NAKAMURA Y, MORIYA $\mathrm{T}$, et al. Peroxisome proliferator-activated receptor gamma in human breast carcinoma: a modulator of estrogenic actions. Endocr Relat Cancer 2006; 13: 233-250 http://dx.doi. org/10.1677/erc.1.01075

[28] GLEASON DF. Histologic grading of prostate cancer: a perspective. Hum Pathol 1992; 23: 273-9. http://dx.doi. org/10.1016/0046-8177(92)90108-F

[29] ABRAHAMSSON PA. Neuroendocrine cells in tumour growth of the prostate. Endocr Relat Cancer 1999; 6: 503-519 http://dx.doi.org/10.1677/erc.0.0060503

[30] STANGELBERGER A, SCHALLY AV, VARGA JL, ZARANDI $\mathrm{M}$, SZEPESHAZI $\mathrm{K}$, et al. Inhibitory effect of antagonists of bombesin and growth hormone-releasing hormone on orthotopic and intraosseous growth and invasiveness of PC-3 human prostate cancer in nude mice. Clin Cancer Res 2005; 11: 49-57

[31] SAUNDERS PT, MILLAR MR, MACPHERSON S, IRVINE DS, GROOME NP, et al. ERbeta1 and the ERbeta2 splice variant (ERbetacx/beta2) are expressed in distinct cell populations in the adult human testis. J Clin Endocrinol Metab 2002; 87: 2706-2715 http://dx.doi.org/10.1210/jc.87.6.2706
[32] GASKELL TL, ROBINSON LL, GROOME NP, ANDERSON RA, SAUNDERS PT. Differential expression of two estrogen receptor beta isoforms in the human fetal testis during the second trimester of pregnancy. J Clin Endocrinol Metab 2003; 88: 424-432 http://dx.doi.org/10.1210/jc.2002$\underline{020811}$

[33] PARK BW, KIM KS, HEO MK, YANG WI, KIM SI, et al. The changes of estrogen receptor-beta variants expression in breast carcinogenesis: Decrease of estrogen receptor-beta2 expression is the key event in breast cancer development. J Surg Oncol 2006; 93: 504-510 http://dx.doi.org/10.1002/ jiso. 20336

[34] ESSLIMANI SAHLA M, KRAMAR A, SIMONY LAFONTAINE J, WARNER M, GUSTAFSSON JA, et al. Increased estrogen receptor betacx expression during mammary carcinogenesis. Clin Cancer Res 2005; 11: 3170-3174 http:// dx.doi.org/10.1158/1078-0432.CCR-04-2298

[35] POOLA I, ABRAHAM J, LIU A. Estrogen receptor beta splice variant mRNAs are differentially altered during breast carcinogenesis. J Steroid Biochem Mol Biol 2002; 82: 169-179 http://dx.doi.org/10.1016/S0960-0760(02)00185-1

[36] CRITCHLEY HO, HENDERSON TA, KELLY RW, SCOBIE GS, EVANS LR, et al. Wild-type estrogen receptor (ERbeta1) and the splice variant (ERbetacx/beta2) are both expressed within the human endometrium throughout the normal menstrual cycle. J Clin Endocrinol Metab 2002; 87: 5265-5273 http://dx.doi.org/10.1210/jc.2002-020502

[37] SHUPNIK MA, PITT LK, SOH AY, ANDERSON A, LOPES MB, et al. Selective expression of estrogen receptor alpha and beta isoforms in human pituitary tumors. J Clin Endocrinol Metab 1998; 83: 3965-3972 http://dx.doi. org/10.1210/jc.83.11.3965 